\title{
A MATURITY MODEL FOR ENERGY EFFICIENCY IN MATURE DATA CENTRES
}

\author{
Edward Curry ${ }^{1}$, Gerard Conway ${ }^{2}$, Brian Donnellan ${ }^{2}$, Charlie Sheridan ${ }^{3}$ and Keith Ellis ${ }^{3}$ \\ ${ }^{1}$ Digital Enterprise Research Institute, National University of Ireland, Galway \\ ${ }^{2}$ Innovation Value Institute, National University of Ireland, Maynooth \\ ${ }^{3}$ Intel Labs Europe, Intel Corporation \\ ed.curry@deri.org,gerard.conway@nuim.ie,brian.donnellan@nuim.ie,charles.g.sheridan@intel.com, \\ keith.a.ellis@intel.com
}

Keywords: Data Centre, Energy Efficiency, Maturity Model, Data Centre Management, IT Management

Abstract: Data centres are complex eco-systems that interconnect elements of the ICT, electrical, and mechanical fields of engineering and hence the efficient operation of a data centre requires a diverse range of knowledge and skills from each of these fields. The Innovation Value Institute (IVI), a consortium of leading organizations from industry, the not for profit sector, and academia, have developed a maturity model that offers a comprehensive, value-based method for organizing, evaluating, planning, and improving the energy efficiency of mature data centres. The development process for the maturity model is discussed, detailing the role of design science in its definition.

\section{INTRODUCTION}

According to McKinsey \& Co. (Forrest \& Kaplan, 2008 ) the world's 44 million servers consume $0.5 \%$ of all electricity and produce $0.2 \%$, or 80 megatons, of carbon dioxide emissions a year. Given a business as usual scenario, by 2020 greenhouse gas emissions from Data Centres (DCs) are projected to more than double from 2007 levels (Webb, 2008). The efficient operation of a data centre requires a diverse range of knowledge and skills from a large ecosystem of stakeholders. A DC requires expertise from engineering (including electrical, civil, mechanical, software, and electronic) to accountancy to systems management. The Innovation Value Institute (IVI), a consortium of leading organizations from industry (including, Microsoft, Intel, SAP, Chevron, Cisco, The Boston Consultancy Group, Ernst \& Young, and Fujitsu), the not for profit sector, and academia, has developed and tested a maturity model for systematically assessing and improving energy efficient capabilities within mature DCs. The model offers a comprehensive, value-based model for organizing, evaluating, planning, and managing DC capabilities for energy efficiency and fits within IVI's IT-Capability Maturity Framework (IT-CMF) for managing IT. The model provides a high-level assessment of maturity for IT managers with responsibility for DC operations.

\section{DC ENERGY COMSUMPTION}

Power usage within a DC goes beyond the direct power needs of servers to include networking, cooling, lighting, and facilitie. Power draws for DCs range from a few kilowatts for a rack of servers to several tens of megawatts for large facilities. While the exact breakdown of power usage will vary between individual DCs, Figure 1 illustrates the examination of one DC where up to $88.8 \%$ of the power consumed by the DC was not used on computation (U.S. EPA, 2007). International Data Corporation (IDC) estimates that DC energy costs will be higher than equipment costs by 2015 (Martinez \& Bahloul, 2008). The cost of operating a DC goes beyond the economic bottom line; there is also an environmental cost. DCs are the fastest growing contributor to the IT sectors environmental footprint and are predicted to grow to $259 \mathrm{MtCO} 2 \mathrm{e}$ by 2020, up from $76 \mathrm{MtCO} 2 \mathrm{e}$ in 2002 (Webb, 2008).

\section{DC ENERGY EFFICIENCY}

With electricity costs being the dominant operating expense of a DC, it is vital to maximize the operational efficiency in order to reduce both the environmental and economic cost. Energy efficient DC operations require a holistic approach to both IT and facilities energy management. DC and IT leaders are often unable to find satisfactory answers to questions such as:

- What is the utilization of the DC?

- How energy efficient is the DC?

- Are there clear measurable goals and objectives for DC energy efficiency (EE)?

- What is the roadmap for DC EE improvements?

IT departments face additional challenges - such as the introduction of new methods and tools, and conformance to industry metrics and standards which are compounded by a general lack of relevant information, such as power consumption quantifications. Mature DCs typically have a heterogeneous IT infrastructure with fixed support systems, making it arduous to employee catch-all solutions. 


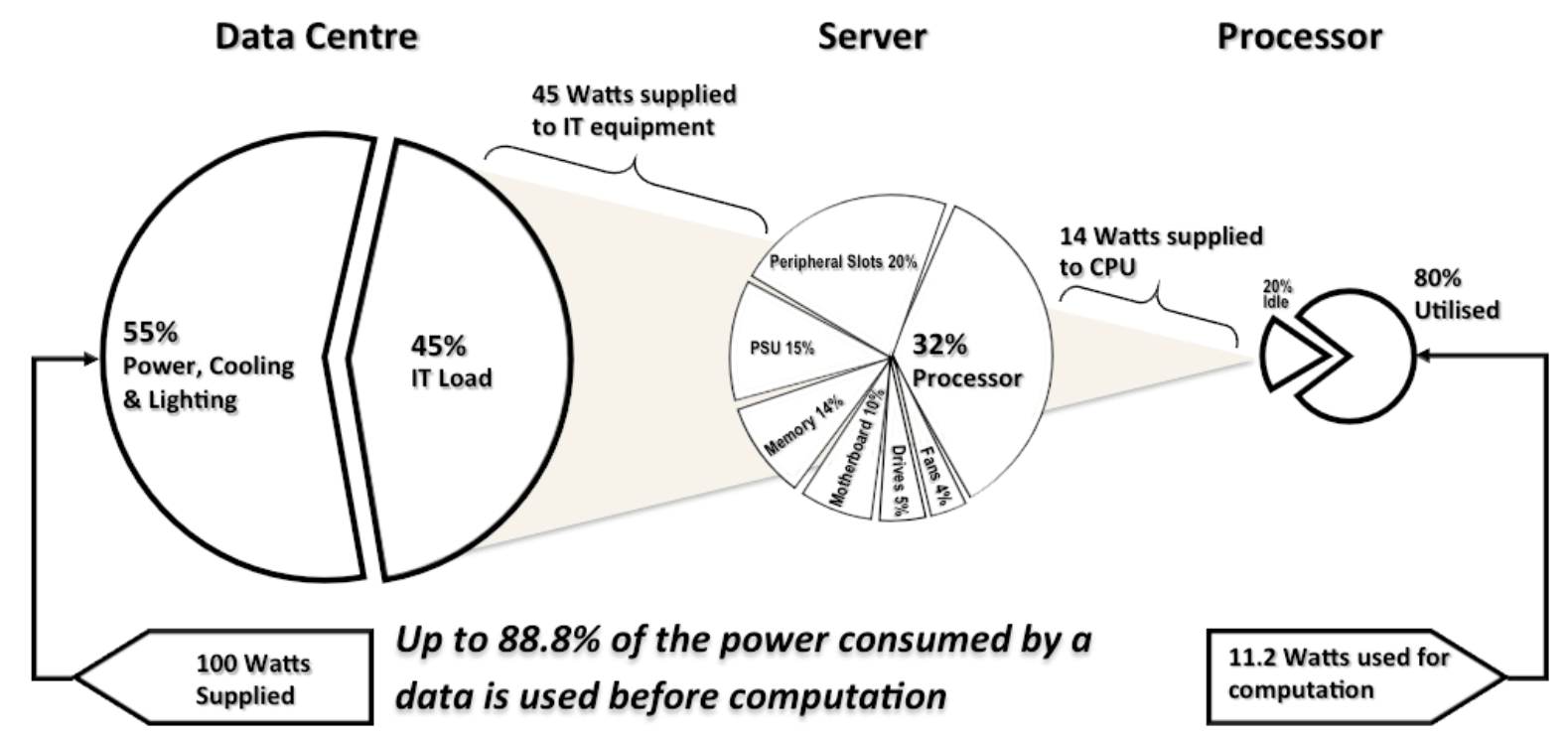

Figure 1. Example breakdown of power usage within a Data Centre

\section{THE NEED FOR A MATURITY MODEL}

Maturity models are tools that have been used to improve many capabilities within organizations, from Business Process Management (BPM) (Rosemann \& De Bruin, 2005) to Software Engineering (CMMI) (Paulk, Curtis, Chrissis, \& Weber, 1993). Maturity models have also been developed to support the management of IT organizations. IVI have developed the IT-Capability Maturity Framework (IT-CMF) (Curley, 2004) that provides a high-level process capability maturity framework for managing the IT function within an organization to deliver greater value from IT by assessing and improving a broad range of management practices. A core function of IT-CMF is to act as an assessment tool and a management system.

There is a need to improve the behaviours, practices, and processes within DCs in order to deliver greater energy efficiency. To address this need, the IVI consortium has extended the IT-CMF with a maturity model for systematically assessing and improving DC capabilities for energy efficiency.

\subsection{Design Methodology}

The development of the model was undertaken using a design process with defined review stages and development activities based on the Design Science Research (DSR) guidelines advocated by Hevner et al. (Hevner, March, Park, \& Ram, 2004). During the design process, researchers participate together with practitioners within a working group to research and develop the model. The working group interviewed multiple DC stakeholders to capture the views of key domain experts and to understand current practice and barriers to improving DC energy efficiency (EE). The working group widely consulted the relevant literature, both industrial and academic, on DC EE. Industrial best practices - including the EU code of conduct for DC EE and the work of the Green Grid on metrics - were incorporated. The initial maturity model was developed in mid-2010 and has been piloted within a number of DCs, with learning and feedback incorporated into subsequent versions.

\section{MATURITY MODEL}

The Data Centre EE model offers a comprehensive, value-based model for organizing, evaluating, planning, and managing DC EE capabilities. The model fits within IT-CMF (Curley, 2004) and is aligned with the broader Sustainable ICT critical capability (Curry \& Donnellan, 2012; Donnellan, Sheridan, \& Curry, 2011).

The DC EE assessment methodology determines how different DC capabilities are contributing to energy efficiency goals and objectives. The gap analysis between what energy efficiency targets are, and what they are actually achieving, positions the Data Centre EE model as a management tool for aligning relevant capabilities with EE objectives. The model focuses on the execution of four key actions to improve the management of EE in the DC:

- Define goals and objectives for the DC program

- Understand the current DC maturity level,

- Systematically develop and manage the DC capability building blocks.

- Assess and manage DC progress over time.

\subsection{Capability Building Blocks}

The Data Centre EE model consists of seven capability building blocks (see Table 2) in the categories of Management, Operations, and Building. The maturity level for each of the seven Capability Building Blocks is presented in Table 1. 
Table 2: Capability Building Blocks of Energy Efficicent Data Centres

\begin{tabular}{|c|c|c|}
\hline & Capability & Description \\
\hline \multirow{3}{*}{ 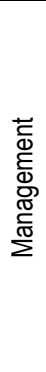 } & $\begin{array}{l}\text { Organizational } \\
\text { Structure }\end{array}$ & $\begin{array}{l}\text { How the data centre and its energy } \\
\text { efficiency is managed, who is responsible for } \\
\text { running the DC, and how integrated are: IT, } \\
\text { Facilities, and the Business. }\end{array}$ \\
\hline & Policy & $\begin{array}{l}\text { The policies in place for energy efficiency } \\
\text { within the the } D C \text { and how they are aligned } \\
\text { across the enterprise. }\end{array}$ \\
\hline & $\begin{array}{l}\text { Manageability } \\
\text { and Metering }\end{array}$ & $\begin{array}{l}\text { The metering use by IT and Facilities to } \\
\text { improve understanding and manageability of } \\
\text { energy usage. }\end{array}$ \\
\hline 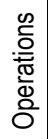 & $\begin{array}{l}\text { IT Infrastructure } \\
\text { and Services }\end{array}$ & $\begin{array}{l}\text { The management of IT equipment and } \\
\text { services to ensure energy efficiency. }\end{array}$ \\
\hline \multirow{3}{*}{$\frac{\text { 음 }}{\frac{.0}{\overline{5}}}$} & $\begin{array}{l}\text { Internal Air and } \\
\text { Cooling }\end{array}$ & $\begin{array}{l}\text { The internal air manageemnt techniques } \\
\text { employed. }\end{array}$ \\
\hline & Cooling Plant & $\begin{array}{l}\text { The design and management of the cooling } \\
\text { system. }\end{array}$ \\
\hline & $\begin{array}{l}\text { Power } \\
\text { Infrastructure }\end{array}$ & $\begin{array}{l}\text { The management of power generation, and } \\
\text { conditioning and delivery systems to } \\
\text { maximize energy efficiency. }\end{array}$ \\
\hline
\end{tabular}

\subsection{Assessment Approach}

The assessment begins with an online survey of DC stakeholders in order to understand their individual assessments of the maturity and the importance of these capabilities. Typically, a range of individuals who are involved in, or accountable for, EE for the DC complete the survey. A series of targeted interviews with key stakeholders augments the survey to understand key business priorities and energy efficiency drivers, successes achieved, and initiatives taken or planned. Interviews last between 60 and 90 minutes; they are used to support the survey data.

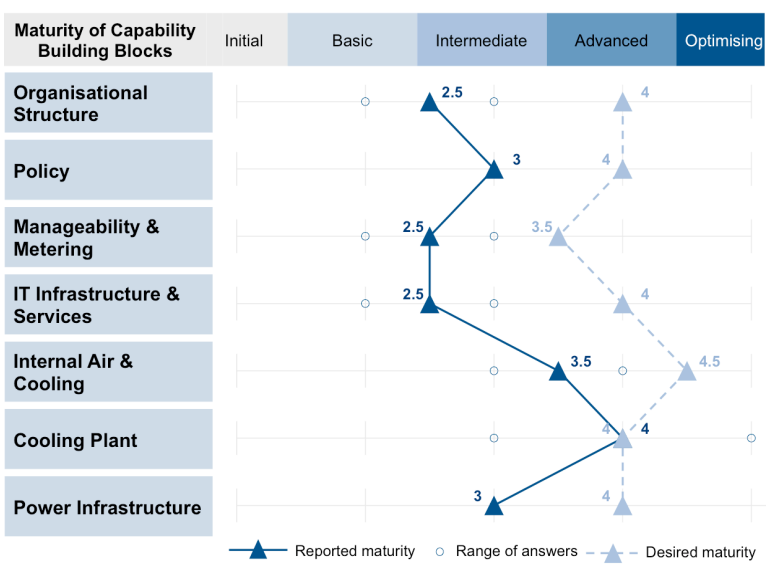

Figure 2. Reported vs. Desired Maturity

When the assessment is complete, organizations will have a clear view of current capability and key areas for action and improvement. A smaple pilot assessment result in illustrated in Figure 2. However, to further develop the capability, the organization should assess and manage progress over time by using the assessment results to 1) develop a roadmap and action plan and 2) add a yearly/half-yearly follow-up assessment to the overall DC energy efficiency management process.

\section{SUMMARY AND FUTURE WORK}

The IVI consortium has developed and tested a maturity model for systematically assessing and improving Energy Efficient capabilities within mature Data Centres. The resulting model offers a comprehensive, value-based model for organizing, evaluating, planning, and improving the energy efficiency of mature data centres. Further development and evaluation of the model is planned in particular, the use of the model in conjunction with metrics such as PUE, CUE, WUE, and CapEx/OpEx costs - in order to quantify benefits. We are also employing the model to benchmark DCs within the IVI consortium to faciliate comparisons between DCs across and between industrial sectors.

\section{ACKNOWLEDGMENT}

We would like to recognize the contribution of the members of the IVI's Data Center Energy Efficiency Working Group. Enterprise Ireland funded part of the work presented in this paper under Grant CC/2009/0801.

\section{REFERENCES}

Curley, M. (2004). Managing Information Technology for Business Value: Practical Strategies for IT and Business Managers (p. 350). Intel Press,.

Curry, E., \& Donnellan, B. (2012). Understanding the Maturity of Sustainable ICT. In J. vom Brocke \& S. Seidel (Eds.), Green Business Process Management-Towards the Sustainable Enterprise. Springer.

Donnellan, B., Sheridan, C., \& Curry, E. (2011). A Capability Maturity Framework for Sustainable Information and Communication Technology. IEEE IT Professional, 13(1), 33-40. doi:10.1109/MITP.2011.2

Forrest, W., \& Kaplan, J. M. (2008). Data centers : How to cut carbon emissions and costs. McKinsey on Business Technology, 14(6).

Hevner, A. R., March, S. T., Park, J., \& Ram, S. (2004). Design Science in Information Systems Research. MIS Quarterly, 28(1), 75-105. MIS RESEARCH CENTER-SCHOOL OF MANAGEMENT. doi:10.2307/249422

Martinez, N., \& Bahloul, K. (2008). Green IT Barometer European Organisations and the Business Imperatives of Deploying a Green and Sustainable IT Strategy. International Data Corporation. Retrieved from

http://content.dell.com/us/en/corp/d/corporate $\sim$ research $\sim$ en/ Doc uments idcwp28q.pdf.a

Paulk, M. C., Curtis, B., Chrissis, M. B., \& Weber, C. V. (1993). The Capability Maturity Model for Software. Software engineering project management, 10(CMU/SEI-93-TR-24 ESC-TR-93-177), 1-26. Wiley India Pvt. Ltd.

Rosemann, M., \& De Bruin, T. (2005). Towards a Business Process Management Maturity Model. In D. Bartmann, F. Rajola, J. Kallinikos, D. Avison, R. Winter, P. Ein-Dor, J. Becker, et al. (Eds.), 13th European Conference on Information Systems (Vol. 53, pp. 521-532). Citeseer. doi:10.1007/s1 1225-008-9119-4

U.S. EPA. (2007). Report to Congress on Server and Data Center Energy Efficiency Public Law 109-431 (Vol. 109, p. 431).

Webb, M. (2008). SMART 2020: Enabling the low carbon economy in the information age. The Climate Group London. 
Table 1: Capability Building Blocks of Energy Efficicent Data Centres

\begin{tabular}{|c|c|c|c|c|c|}
\hline & Level 1 & Level 2 & Level 3 & Level 4 & Level 5 \\
\hline $\begin{array}{l}\text { Organizational } \\
\text { Structure }\end{array}$ & $\begin{array}{l}\text { No formal } \\
\text { organizational } \\
\text { structure }\end{array}$ & $\begin{array}{l}\text { Resource efficiency } \\
\text { is considered by IT } \\
\text { and facilities, but } \\
\text { there remains a } \\
\text { siloed or disjointed } \\
\text { approach. }\end{array}$ & $\begin{array}{l}\text { Resource efficiency is } \\
\text { inherent in policies. } \\
\text { Management of the } \\
\text { DC takes account of } \\
\text { the interrelationship of } \\
\text { IT and Facilities. }\end{array}$ & $\begin{array}{l}\text { Holistic management } \\
\text { approach with } \\
\text { decisions balancing } \\
\text { sustainability, } \\
\text { resilience, and } \\
\text { business needs. }\end{array}$ & $\begin{array}{l}\text { A team led by a senior } \\
\text { manager has } \\
\text { responsibility for } \\
\text { Resource Efficiency } \\
\text { across the enterprise. }\end{array}$ \\
\hline Policy & $\begin{array}{l}\text { No formal resource } \\
\text { efficiency policies in } \\
\text { place }\end{array}$ & $\begin{array}{l}\text { IT policies have } \\
\text { limited } \\
\text { consideration for } \\
\text { decommissioning, } \\
\text { consolidation, } \\
\text { refresh, efficient } \\
\text { storage allocation, } \\
\text { and virtualization. } \\
\text { Policy creation is } \\
\text { essentially siloed. }\end{array}$ & $\begin{array}{l}\text { Policy moves towards } \\
\text { increased } \\
\text { virtualization. Facilities } \\
\text { have a defined } \\
\text { improvement roadmap } \\
\text { that targets } \\
\text { sustainable } \\
\text { operations. External } \\
\text { best practices are } \\
\text { systematically } \\
\text { reviewed and } \\
\text { internalised. }\end{array}$ & $\begin{array}{l}\text { Policies reflect a } \\
\text { harmonised, } \\
\text { process-based } \\
\text { approach. Resource } \\
\text { efficiency is a criterion } \\
\text { in terms of service } \\
\text { offerings and } \\
\text { purchases. There are } \\
\text { CapEx funding } \\
\text { programmes for } \\
\text { upgrading } \\
\text { infrastructure. }\end{array}$ & $\begin{array}{l}\text { DC resource efficiency } \\
\text { policy is a continuum } \\
\text { from the enterprise } \\
\text { level to the software } \\
\text { code level and } \\
\text { everything in between. }\end{array}$ \\
\hline $\begin{array}{l}\text { Manageability } \\
\text { and Metering }\end{array}$ & $\begin{array}{l}\text { No specific } \\
\text { energy-related } \\
\text { metrics or metering } \\
\text { capability in place. }\end{array}$ & $\begin{array}{l}\text { Basic information } \\
\text { systems exist for } \\
\text { energy data } \\
\text { analysis and } \\
\text { decision support. IT } \\
\text { electrical load } \\
\text { measures at the } \\
\text { UPS level. PUE } \\
\text { and DCiE are used. }\end{array}$ & $\begin{array}{l}\text { The IT organization } \\
\text { has a granular } \\
\text { understanding of its IT } \\
\text { electrical load. } \\
\text { Facilities have an } \\
\text { increased level of the } \\
\text { support infrastructure } \\
\text { metered. }\end{array}$ & $\begin{array}{l}\text { IT has rack and server- } \\
\text { level consumption } \\
\text { data, together with } \\
\text { environmental data } \\
\text { such as temperature } \\
\text { and humidity. Facilities } \\
\text { infrastructure is } \\
\text { completely metered } \\
\text { from an energy } \\
\text { standpoint. }\end{array}$ & $\begin{array}{l}\text { IT can measure } \\
\text { electrical load at the } \\
\text { service level, matching } \\
\text { consumption to useful } \\
\text { work done. Facilities } \\
\text { infrastructure and IT } \\
\text { infrastructure is } \\
\text { completely metered } \\
\text { with appropriate, } \\
\text { optimized automation. }\end{array}$ \\
\hline $\begin{array}{l}\text { IT } \\
\text { Infrastructure } \\
\text { \& Services }\end{array}$ & Ad hoc & $\begin{array}{l}\text { Defined IT landing } \\
\text { procedures } \\
\text { consider resource } \\
\text { efficiency. There is } \\
\text { auditing and } \\
\text { decommissioning of } \\
\text { unused equipment. }\end{array}$ & $\begin{array}{l}\text { A comprehensive } \\
\text { consolidation } \\
\text { programme is in } \\
\text { place. DC has moved } \\
\text { some legacy services } \\
\text { to virtualized } \\
\text { environments. }\end{array}$ & $\begin{array}{l}\text { Virtualization is the } \\
\text { default practice for } \\
\text { server and storage } \\
\text { provisioning. }\end{array}$ & $\begin{array}{l}\text { DC is almost } \\
\text { exclusively virtualized. } \\
\text { Dynamic service } \\
\text { management allows for } \\
\text { transferable workloads. } \\
\text { IT moves towards a } \\
\text { machine-readable SLA. }\end{array}$ \\
\hline $\begin{array}{l}\text { Internal Air \& } \\
\text { cooling }\end{array}$ & $\begin{array}{l}\text { Ad hoc design and } \\
\text { operation }\end{array}$ & $\begin{array}{l}\text { IT Equipment is } \\
\text { oriented in a cold } \\
\text { aisle/hot aisle } \\
\text { configuration. }\end{array}$ & $\begin{array}{l}\text { Air inlet supply } \\
\text { temperature is at the } \\
\text { lower end of the } \\
\text { ASHRAE } \\
\text { recommendation. } \\
\text { Row-based cooling } \\
\text { maybe utilised. }\end{array}$ & $\begin{array}{l}\text { Full air segregation is } \\
\text { in place. There is cold } \\
\text { aisle/hot aisle, chimney } \\
\text { cabinets, or in-rack } \\
\text { cooling. CRAC/CRAH } \\
\text { have VFDs. }\end{array}$ & $\begin{array}{l}\text { An optimal, floating, } \\
\text { HUM setpoint is used. } \\
\text { DC normal operational } \\
\text { mode is 'free-cooling' } \\
\text { economization. }\end{array}$ \\
\hline Cooling Plant & $\begin{array}{l}\text { Cooling is typically } \\
\text { supplied based on } \\
\text { resilience }\end{array}$ & $\begin{array}{l}\text { Refrigeration } \\
\text { infrastructure is } \\
\text { appropriately sized } \\
\text { or strategies are in } \\
\text { place to align } \\
\text { cooling capacity } \\
\text { and demand. }\end{array}$ & $\begin{array}{l}\text { COP is typically } \sim 4-6 \text {. } \\
\text { Pumps have VFDs. } \\
\text { Partial wet side or } \\
\text { airside economization } \\
\text { is increasingly utilised } \\
- \text { for } \sim 50 \% \text { of the } \\
\text { year. }\end{array}$ & $\begin{array}{l}\text { Refrigeration fans and } \\
\text { pumps have VFDs. } \\
\text { COP is typically } \sim 6 \text { or } \\
\text { greater and normal } \\
\text { operation is eco mode } \\
\text { for } ~ 75 \% \text { of the year. } \\
\text { Wet side eco / } \\
\text { evaporation or direct } \\
\text { free air cooling utilised. }\end{array}$ & $\begin{array}{l}\text { Evaporative cooling } \\
\text { (wet side } \\
\text { economization), or, } \\
\text { where possible, direct } \\
\text { free air cooling is used. } \\
\text { Direct touch cooling or } \\
\text { new technologies } \\
\text { maybe utilised. }\end{array}$ \\
\hline $\begin{array}{l}\text { Power } \\
\text { Infrastructure }\end{array}$ & $\begin{array}{l}\text { Power is typically } \\
\text { supplied on a } \\
\text { resilience basis } \\
\text { only. }\end{array}$ & $\begin{array}{l}\text { UPS is more } \\
\text { effectively sized or } \\
\text { strategies are } \\
\text { employed to more } \\
\text { appropriately align } \\
\text { demand and } \\
\text { capacity relative to } \\
\text { existing IT load. }\end{array}$ & $\begin{array}{l}\text { UPS is correctly sized. } \\
\text { UPS is typically } ~ 93 \% \\
\text { efficient or above at } \\
50 \% \text { load. There is an } \\
\text { optimal number of } \\
\text { PDUs. }\end{array}$ & $\begin{array}{l}\text { UPS is correctly sized } \\
\text { to DC load. } \\
\text { Redundancy is } \\
\text { appropriate for the } \\
\text { criticality of the load. } \\
\text { Rack PDUs are } \\
\text { efficient with less than } \\
3 \% \text { loss. Power is } \\
\text { delivered on a dynamic } \\
\text { basis. }\end{array}$ & $\begin{array}{l}\text { UPS is modular and } \\
\text { efficient for the given } \\
\text { DC. Appropriate non- } \\
\text { critical applications are } \\
\text { on mains-only power. } \\
\text { Renewable energy } \\
\text { sources are integrated, } \\
\text { possibly utilizing direct } \\
\text { current in major retro-fit } \\
\text { scenarios. }\end{array}$ \\
\hline
\end{tabular}

